Int. J. Electrochem. Sci., 12 (2017) $2194-2206$

International Journal of

ELECTROCHEMICAL

SCIENCE

www.electrochemsci.org

\title{
Methanol Electrooxidation Reaction in Alkaline Medium on Glassy Carbon Electrode Modified with Ordered Mesoporous $\mathrm{Ni} / \mathrm{Al}_{2} \mathrm{O}_{3}$
}

Yan Wang, Wei Chen, Dahai Pan, Qian Xu, Jinghong Ma, Jiajun Zheng, Ruifeng Li ${ }^{*}$

College of Chemistry and chemical Engineering, Taiyuan University of Technology, Taiyuan, 030024, People's Republic of China

*E-mail: rfli@tyut.edu.cn

doi: $10.20964 / 2017.03 .47$

Received: 17 November 2016 / Accepted: 18 January 2017 / Published: 12 February 2017

In this work, ordered mesoporous $\mathrm{Ni} / \mathrm{Al}_{2} \mathrm{O}_{3}$ catalysts were prepared by the solvent evaporation induced self-assembly (EISA) method. The synthesized $\mathrm{Ni} / \mathrm{Al}_{2} \mathrm{O}_{3}$ catalysts were characterized by XRD, elemental distribution analyses, $\mathrm{N}_{2}$ adsorption and TEM. Ni/ $\mathrm{Al}_{2} \mathrm{O}_{3}$ modified glassy carbon electrode was used to investigate the electrocatalytic oxidation of methanol in $0.1 \mathrm{M} \mathrm{NaOH}$ solution by cyclic voltammetry (CV) and chronoamperometry (CA). CVs results showed good electrocatalytic activity of $\mathrm{Ni} / \mathrm{Al}_{2} \mathrm{O}_{3}$ for methanol electrooxidation in alkaline electrolytes. The good methanol electrooxidation activity of $\mathrm{Ni} / \mathrm{Al}_{2} \mathrm{O}_{3}$ could be attributed to its synergetic effects between high dispersion of nickel and the ordered mesoporous structure that facilitates the diffusion of methanol and products. The CV and CA results suggest methanol electrooxidation is an irreversible process and a diffusion controlled process. The rate constant for the catalytic reaction of methanol is calculated to be $1.66 \times 10^{6} \mathrm{~cm}^{3} \mathrm{~mol}^{-1}$ $\mathrm{s}^{-1}$.

Keywords: Methanol Electrooxidation, Glassy Carbon Electrode, Direct Methanol Fuel Cell, Alkaline Medium

\section{$\underline{\text { FULL TEXT }}$}

(C) 2017 The Authors. Published by ESG (www.electrochemsci.org). This article is an open access article distributed under the terms and conditions of the Creative Commons Attribution license (http://creativecommons.org/licenses/by/4.0/). 